\title{
Forum
}

PMLA invites members of the association to submit letters, printed and doublespaced, that comment on articles in previous issues or on matters of general scholarly or critical interest. The editor reserves the right to reject or edit Forum contributions and offers the PMLA authors discussed in published letters an opportunity to reply. Submissions of more than one thousand words are not considered. The journal omits titles before persons' names and discourages endnotes and works-cited lists in the Forum. Letters should be addressed to PMLA Forum, Modern Language Association, 26 Broadway, 3rd floor, New York, NY 10004-1789.

\section{Citizenship and Cosmopolitanism}

\section{To THE EDITOR:}

Although I applaud Domna C. Stanton for her energetic and interesting Presidential Address, "On Rooted Cosmopolitanism” (120 [2006]: 627-40), and I thank her for making the Presidential Forum a site of exciting intellectual debate, I believe that the distinctions she raises between citizenship and cosmopolitanism are too stark. As a result, the goals she sets may appear unattainable or abstract to many readers and thus may seem beyond the reach of our daily work. I propose the following thoughts as a supplement to her stirring vision for the future.

First of all, as a dix-huitiémiste, I beg to differ with her view of the French Revolution and nationalism. Let us recall that the revolutionaries of 1789-92 envisioned inspiring a movement for constitutional governmentfirst monarchical, then democratic-that would reach out and transcend national borders to touch citizens wherever they lived and free them from the unjust systems of taxation, political hierarchy, and religious oppression that held them enslaved. That this early republican project went astray cannot be denied, but it is important to remember that the revolution of 1793-94 developed in directions unwelcome to its forebears, and the virile nationalism that developed in 1799 and on through the years of Napoleon's empire was for many people a travesty of the republican ideal.

Second, I cringe at the stark connotations that oppose citizenship and cosmopolitanism in Stanton's essay. Does citizenship necessarily signal participation in an avid nationalism? And does cosmopolitanism have to connote a rootless and disembodied kind of political discourse? I argue that we should aim for a combination: to be both citizens and cosmopolitans. Not only should we aim for this goal, we should realize that many of our students already achieve it.

By citizenship, I mean that we scholars must be fully rooted in our local polis, here and now. Involved, engaged, and politically versed in issues of

(C) 2007 BY THE MODERN LANGUAGE ASSOCIATION OF AMERICA 
import, whether it be in South Bend, Indiana, or in Santiago, Chile. I have seen too many colleagues in my fifteen years at Notre Dame scorn our local community and refuse to live in town, read the local newspaper, or send their children to local public schools out of a snobbish sense of cultural superiority that ultimately robs our city of one of its primary lifelines: citizens who invest time, money, and ideas to the improvement of their environment.

Without pursuing the hostility this attitude imposes on our community, I propose we consider the spiritual desert that such a life suggests. Consider the following, adapted from Scott Russell Sanders's Staying Put:

"The man who is often thinking that it is better to be somewhere else than where he is excommunicates himself," wrote Thoreau. The metaphor is religious: to withhold yourself from where you are is to be cut off from communion with the source. One cannot have a spiritual center without having a geographical one; one cannot live a grounded life without being grounded in a place.

In belonging to a landscape, one feels a rightness, at-homeness, a knitting of self and world. This condition of clarity and focus, this being fully present is akin to what the Buddhists call mindfulness, what Christian contemplatives refer to as recollection, what Quakers call centering down. There is only one world, and we participate in it here and now, in our flesh and our place.

How does this mesh with cosmopolitanism? And how are our students already living the vision? Through study and service at sites abroad.

At Notre Dame, we place great emphasis on community service-in town and in every site where students go to study for a semester or year abroad. As assistant provost for international studies, I insist that students take an active role in local communities wherever they enroll: through service, theater, sports, internships, or spiritual activities. I have found it heartening in my site visits around the world to learn that many students are already taking time to serve their local communities by teaching English (in France, Japan, and Chile), by providing support to displaced peoples (in Uganda), or by volunteering in a vari- ety of governmental offices (in Belgium, England, and Spain). Many return to these sites for more sustained research or service projects at a later date, as well, and they sustain friendships with host families, classmates, colleagues, and professors over a lifetime.

Through this engagement our students embody a kind of ongoing cosmopolitanism that we, as professors of language and literature, would do well to emulate. Our ongoing scholarship is crucial. But without making the human connections that feed our local communities-here and now, or there and then, wherever we happen to be-our scholarship will always be a hollow accomplishment.

Stanton is right: we must always be making connections, writing and reading communications with people from afar. But cosmopolitanism need not co-opt or abort efforts at grassroots citizenship. They can and must work hand in hand to make the professoriat a truly engaged segment of the population. Let it happen to us.

Julia Douthwaite University of Notre Dame

\section{Reply:}

I am pleased that Julia Douthwaite casts her letter as a "supplement" to my address, "On Rooted Cosmopolitanism.” However, I am puzzled by her criticisms since our texts share essentially the same views.

Her question "does cosmopolitanism have to connote a rootless and disembodied kind of political discourse?" is particularly perplexing as a response to a paper whose title and content explore the complexities of a "rooted cosmopolitanism." Douthwaite states that in contrast to my views, she believes "that we scholars must be fully rooted in our local polis." But I specifically refuse the opposition between cosmopolitanism and the nation and argue that "such binary thinking must be rejected in favor of a more capacious view that encompasses both the national and the transnational, the local and the global" and, again, that "cosmopolitanism must be a practice that is both local and global in context-specific doses"; put another way, I emphasize that we each have "multiple belongings," "a circle of enlarging allegiances," among which the local is prominent (636-37). 
While I did not specifically focus on students in an address to the members of the MLA, I applaud Douthwaite's efforts to engage students both in local community activities and in work abroad. My talk urges the members of the MLA to think of our work as a cosmopolitan practice: "I want to argue that what we, the teacher-scholars of the MLA, do in our many diverse ways is to exemplify and promote a cosmopolitan education and to engage in research and writing whose impulses and goals embody cosmopolitan thinking" (629). In particular, I cite Claire Kramsch's notion of learning a "foreign" language as a dialogic cultural practice, Anthony Appiah's model of conversation for both teaching and criticism, and Martha Nussbaum's ideal of a cosmopolitan education (629-32). I then try to refine David Damrosch's conception of world literature into a truly cosmopolitan practice based on knowledge of other languages.

I find one area of disagreement with Douthwaite, which involves what she believes are facts at the end of the eighteenth century and which I believe centers on the ways in which we read history. Douthwaite maintains that "the virile nationalism that developed in 1799 and on through the years of Napoleon's empire was for many people a travesty of the republican ideal" and insists that we should focus on the original intent of the revolution's "forebears." In my view, it is more important to gauge effects, what historians tell us happened in the 1790s, and not to invoke, in a way that would make Sartre cringe, what republican good intentions were. Indeed, what happened at the end of the eighteenth century bears great relevance for us today. That "a chauvinistic nationalism" (633) undermined cosmopolitanism and republicanism constitutes a crucial lesson for us in the republic of the United States, especially in the aftermath of 9/11 and amid the triumph of jingoistic discourses that pit "us" against "them" and menacingly proclaim, "You are either with us or against us."

Finally, Douthwaite invokes the idea of citizenship several times in her letter and claims that I oppose it to cosmopolitanism. I am surprised, since I do not discuss the connection between citizenship and cosmopolitanism, a complex issue that warrants a book in its own right. But since Douthwaite has raised the issue, I welcome the opportunity to underscore the critical importance of (re)defining citizenship today in a world where, as I wrote, there are dislocations of people (citizens) "in masses that the world has never seen" moving from south to north and east to west looking for work to survive and enduring hostile conditions of noncitizenship (637); where anti-immigrationism has reared its ugly head in a host of countries, including in western European nations historically known for their tolerance (e.g., the Netherlands); and where we have seen on our TV screens (and looked away from) the appalling conditions of refugees in Darfur and on the rooftops and in the Superdome of New Orleans. Who gets to be a citizen in our globalized world? What rights, what human rights do noncitizens have that fail to be upheld by nation-states, and how do we force nation-states to comply with international treaties they have signed? Ultimately, what cosmopolitan vision can encompass the plight of "enemy combatants" at Guantánamo Bay, who exist in the black hole of nonpersonhood with no citizen or human rights? These are indeed questions that we teacher-scholars of the MLA should confront as citizens of the world after $9 / 11$. To be sure, some of us face similar problems in classrooms filled with the children of seasonal workers and immigrants who can't even be called second-class citizens. These defining issues for our time and place should be the subject of many more conversations and reflections and, undeniably, should be the cause for concerted action locally and globally.

Domna C. Stanton

Graduate Center, City University of New York

\section{Eurasia and Imperialism}

\section{To THE EDITOR:}

Many thanks for publishing the conference debate "Are We Postcolonial? Post-Soviet Space" (121 [2006]: 828-36). It is most significant that in this discussion on postcolonialism the term Eurasia was used. To many thinkers and politicians in Russia today, Eurasia does not merely serve as a synonym for post-Soviet, it also represents dreams of a renewed empire. The designation of the postSoviet non-Russian countries as Eurasian would represent a political neocontainment leading to neocolonialism. 
Simply put, Eurasian equates with neocolonial, thus negating the postcolonial in the above title.

Larissa Onyshkevych Shevchenko Scientific Society

Reply:

From her letter, I have a feeling that Larissa Onyshkevych thinks that Eurasia means the forced integration of Ukraine into a Russian-led empire. My use of the expression was simply to acknowledge that the post-Soviet areas are not simply "Europe." I hope this will satisfy her. As a longstanding worker in the field of postcoloniality, I have no interest in endorsing new imperialisms.

\section{Gayatri Chakravorty Spivak Columbia University}

\section{Reply:}

I appreciate Larissa Onyshkevych's contribution to the conference debate "Are We Postcolonial? PostSoviet Space," in which she suggests that postcolonial and Eurasia are mutually canceling concepts. "Eurasian," she suggests unequivocally, "equates with neocolonial." In one sense, we are in agreement: my passing use of the term (830) invoked Eurasia and the Soviet space as more or less coterminous.

Here is where we differ: it makes urgent sense to distinguish among three spheres of meaning for Eurasia. As Onyshkevych knows, the early or classical Eurasia belongs to the Russian émigré community in Europe from the 1920s to the interwar period, whose leaders included the structural linguist Nikolai Trubetskoi (1890-1938), Petr Savitskii (1895-1968), and others. Their central concerns were less the continuity and preservation of the empire (the dynastic empire, after all, had fallen, and they were hardly supporters of the Soviet version) than its differentiation from (and resistance to) a doomed and waning Europe in favor of the contributions of Russia's "Asian" expanses, not only Turkic-Mongol influences but also Finno-Ugric. The appeal and influence of classical Eurasianism can be discerned to this day in both elite and popularized forms, such as the state-sponsored Russian television serial Death of the Empire, which enjoys a similar Spenglerian and Nietzschean incandescence.
A second cluster of meaning around Eurasia-through such transitional, warring figures as the "ethnogeneticist" Lev Gumilev (1912-92) and the ethnographer Iuliian Bromlei-pertains more directly to Onyshkevych's concerns. Arguing in favor of a cultural affinity between Russia and Central Asia, the political activist Aleksandr Dugin, founder in 2002 of the Eurasia Party, has advocated an "imperial conglomeration of the oriental nations, united round Russia" as its "heartland" (http://utenti.lycos.it/EurasianWebSite/ dugin_mnb_eng.html). Attention paid to this concept by such political figures as Kyrgyzstan's first president, Askar Akaev, and the current Kazakhstan president, Nursultan Nazarbaev, suggests that there is indeed much in this conservative-and, in some respects, racist-movement worthy of caution. Of course, it would be as much a mistake to ignore the differences between the classical and contemporary Eurasianists as it would be to conflate Dugin's national-Bolshevik politics with Vladimir Putin's rather consistent neoimperial tactics, yet a certain historical overlay and continuity of interests exists. It is to this potential vested interest in neocontainment that Onyshkevych presumably refers.

A third cluster, which I describe without advocacy, is the search within the academic community for ways to preserve shared research interests, data, and funding. In this context, the comparatist spirit signaled by Eurasia no more endorses neocontainment than the profession's earlier study of communism endorsed Marxism-Leninism or the study of empire today endorses neoimperialism. Were we philosophers, I suppose we might describe this as the fact-value distinction.

If indeed (as the letter suggests) "Eurasian equates with neocolonial," then by this logic neocolonialism has odd bedfellows. The Bureau of European and Eurasian Affairs (State Department), the Davis Center for Russian and Eurasian Studies (Harvard), the National Council for Eurasian and East European Research, and the Eurasia Program (Social Science Research Council), as well as the profession's major journals, such as Slavic Review (“American quarterly of Russian, Eurasian, and East European Studies") and Kritika ("Explorations in Russian and Eurasian History"), would be advocates of neocolonialism - that is to say, a 
Russian policy of neocontainment of neighboring states. Untenable as this idea is, we must turn to the word's multivalence as an explanation for its use by such disparate entities. Language is a pesky business: if Eurasian can mean "neocolonialist," it does not follow that the word must mean only this. How would Onyshkevych adjudicate its meaning, even were she (unwisely) to take up such authority to do so?

Comparatist ambitions are not neocolonial ambitions; conflation of the two discourages the research these agencies and journals support. Implicating Eurasian summarily in neoexpansionism, we run the risk of restricting ourselves intellectually to the nation-state and its symptoms, leaving us unable to address critical issues more inclusive of those cultures for which the nation-state serves as an inhospitable model. Suspending, if only momentarily, the matrix of neoimperialism, we will see that among the research lacunae of the nation-state model (and of sedentary cultures more broadly) is its difficulty in accounting for culture that exists as exilic, itinerant, or borderland practices across a broad, overland expanse. It is not surprising that a former contiguous empire-in contrast to the thalassocratic empires of a more familiar postcolonialism-could have been more deeply marked by these traces and that their study is not reducible to the endorsement of neoexpansionism.

I am sympathetic to the need for Poland and Kyrgyzstan (to choose two distant examples) to enter into political relations as sovereign states rather than as distant points of an immense, overland space-as proper nouns, so to speak, rather than as metonyms of the imperial contiguity. At the same time, important comparatist research continues to trace the cultural, linguistic, and ethnic pathways of border culture-by which I mean not the periphery of but the crossover points between cultures-not adequately captured by the model of the nation-state.

Mark von Hagen and others have made a compelling argument for the cogency of an "emerging reconquista" of the term Eurasia (von Hagen, "Empires, Borderlands, and Diasporas: Eurasia as Anti-paradigm for the Post-Soviet Era" [American Historical Review 109 (2004)]: 448). The jury is still out. If such a reconquista fails, it may be less a rejection of the term's neocolonialist associations than the result of its research subjects' having little in common. Similarly, its success will have less to do with axiological debates than with its usefulness in comparatist research. Yes, the term can be misleading in precisely the ways Onyshkevych productively identifies, but so far we apparently have no better term or else the research community would, I suspect, gladly embrace it.

Nancy Condee

University of Pittsburgh, Pittsburgh

\section{Reply:}

Larissa Onyshkevych expresses timely concern about the dangers inherent in post-Soviet Russia's hegemonic designs in the region. She rightly points out that "neo-Eurasianist" currents in contemporary Russian thought have frequently functioned as an intellectual rationale for Russian hegemony. Eurasia is a toponym with a muddled and unstable history: while in the Russian context it is perhaps vitiated for many by its greatpower connotations, its recent currency in the English-speaking world has more to do with the bureaucratic exigencies of area studies and funding agencies, where it has functioned as a stopgap term for the former Soviet bloc. Some scholars in the West, such as Columbia University's Mark von Hagen, have even sought to ascribe an antiimperialist or at least anticentralist orientation to "Eurasian studies." My work has focused on those writers, philologists, and thinkers, Russian (Velimir Khlebnikov), Kazakh (Olzhas Suleimenov), and Georgian (Grigol Robakidze and others), who might be read as critical Eurasianists-for whom, in other words, the legacy of empire arises as a linguistic and historical problem to be contemplated creatively rather than as a political solution imposed by the center. This much should be evident from my intervention; nor do I believe that any of the other contributors to the PMLA Forum sought to reconstitute the Russian empire. Eurasia remains an ambiguous term: a useful marker of geographic contiguity and shared historical experience but easily equipped with alarming geopolitical fantasies.

Harsha Ram

University of California, Berkeley 


\section{Reply:}

The nonimperialist use of the term Eurasia is akin to the nonpejorative use of the term queer: this practice of strategic reappropriation seemed controversial at first but has become widely accepted in academic discourse. Most readers will be able to distinguish without difficulty between a work of queer theory and a homophobic slur; ditto for the use of the term Eurasia here. However, the problematic past and present uses of the term need to be borne in mind, and it would help if scholars who use this term include a qualifying footnote in their text, especially if the text is addressed to a nonspecialist academic audience.

Vitaly Chernetsky Miami University, Oxford 